2005

\title{
The Law and Politics of Contemporary Transitional Justice
}

Ruti Teitel

New York Law School

Follow this and additional works at: http://digitalcommons.nyls.edu/fac_articles_chapters

Part of the Human Rights Law Commons, International Humanitarian Law Commons, and the International Law Commons

\section{Recommended Citation}

38 Cornell Int'l L.J. 837 (2005)

This Article is brought to you for free and open access by the Faculty Scholarship at DigitalCommons@NYLS. It has been accepted for inclusion in Articles \& Chapters by an authorized administrator of DigitalCommons@NYLS. 


\title{
The Law and Politics of Contemporary Transitional Justice
}

\author{
Ruti Teitel†
}

Introduction

837

I. Historical Phases of Transitional Justice

II. Contemporary Transitional Justice: Milošević and Hussein Trials

A. From Nuremberg to The Hague ................ 841

B. Transitional Justice in the Iraqi Occupation ......... 843

III. Global Transitional Justice: Comparative Perspectives .... 844

A. Transitional Justice and Regime Change........... 845

B. Contemporary Transitional Justice and the Legalist Paradigm

C. Globalizing Justice: Transcending Old Dichotomies .... 849

D. From the International to the Global: From Primacy to Complementarity

E. Universality's Law ......................... 852

IV. Justice at War and for Peace .................. 856

A. Can Justice Buy Peace in Iraq?................. 859

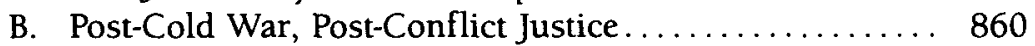

Conclusion ..................................... 861

\section{Introduction}

Slobodan Milošević, Saddam Hussein, Hissène Habré, Augusto Pinochet, Charles Taylor. There have never been more political leaders in the dock, or, under the shadow of its threat. Of what significance are these contemporary instances of transitional justice? This article will use the trials of Slobodan Milošević and Saddam Hussein as an occasion for revisiting and extending my ongoing project of tracing a genealogy of transitional justice.

In prior work, I have defined "transitional justice" as that conception of justice associated with periods of political change. ${ }^{1}$ In an ongoing genealogy, I tie the legal developments in this area to distinct political phases of

$\dagger$ Ernst C. Stiefel Professor of Comparative Law, New York Law School. Many thanks to participants in the Cornell International Law Journal's symposium, the Georgetown Law International Human Rights Colloquium, and to the Yale Law School Schell Center Human Rights Workshop for comments on an earlier draft. My gratitude to Bronwyn Leebaw and Jack Snyder for incisive comments. Thanks to Camille Broussard, Justin Coffee and Theresa Loken for research assistance, and to Stan Schwartz for word-processing assistance.

1. Ruti Teitel, Transitional Justice 3 (2000).

38 CORNELL INT'L L.J. 837 (2005) 
world history, a framework proposed for the study of the law and politics of transitional justice. ${ }^{2}$ In this genealogy, the legal developments are tied to my sense of their varying political purposes. I also endeavor to analyze the extent to which there are trends in the legal changes. Lastly, the discussion of political context and aims ties the genealogy to human thought relating to a history of responses to political conflict, yielding an intellectual genealogy of transitional justice.

Understanding the instant trials here discussed will necessitate an extension of our thinking regarding transitional justice in an attempt to explore latter-day transitional justice. What follows are tentative conclusions about diverse circumstances. The criminal justice processes discussed here present conflicting consequences for the rule of law, further discussed infra, which well reflect the dilemmas of transitional justice written about more extensively in my book Transitional Justice. ${ }^{3}$

One set of questions addressed here relates to the goals of transitional justice and evaluates the shifts in genealogical phases in these terms. Transitional justice evokes many aspirations: rule of law, legitimacy, liberalization, nation-building, reconciliation, and conflict resolution. While the transitions literature appears to presume a goal of "transitions to democracy" as will be seen infra, the democratization goal is often in tension with other aspirations identified here, such as the new focus on conflict resolution and reconciliation. ${ }^{4}$ This proposed genealogy seeks to help identify how these goals shift and map their implications so as to clarify the distinctions between, and the differing implications of, these various aspirations.

The processes discussed here constitute instances of what I have characterized as a paradigm of global transitional justice: an increasing juridicization among diverse legal systems, international and national, and multiple paradigms of legitimacy in global order. Below, these transitional justice responses are further elaborated along these lines. As will be seen, the two trial processes discussed here illustrate these alternative paradigms.

The genealogy proposed here is structured along multiple lines. First, it is organized largely chronologically and illustrates critical cycles divided into three phases of transitional justice. Second, the genealogy is organized largely along a schematic based on the law and politics of the developments associated with the three phases of transitional justice. Third, the genealogical phases are also structured along related intellectual trends, reflecting the connection of the politics of transitional justice in particular, with a trend toward increased juridicization of international affairs, as well as the related politicization of the law. This theme is taken up infra in Part III with a discussion of the aims of contemporary trials.

2. Ruti Teitel, Transitional Justice Genealogy, 16 HaRv. Hum. RTS J. 69, 69 (2003).

3. TEITEL, supra note 1.

4. See generally Human Rights in Transition: Gettrysburg to Bosnia (Carla Hesse $\&$ Robert Post ed., 1999) (discussing reconciliation in Balkans); James L. GIBSON, Overcoming Apartheid: Can Truth Reconcile a Divided Nation? (2004) (discussing reconciliation in South Africa). 


\section{Historical Phases of Transitional Justice}

Modern transitional justice traces back to World War II, as well as the post-World War I period. Transitional justice in the postwar phase ("Phase I") was extraordinary in its internationalism. The Cold War brought an end to this rush of internationalism, however. The second, post-Cold War phase of transitional justice ("Phase II") is associated with the post-1989 wave of democratization, modernization, and nation-building. Finally, toward the end of the twentieth century, global politics was characterized by conflict resolution and a recourse to justice. The third, steady-state phase of transitional justice ("Phase III") is associated with contemporary conditions of persistent conflict which lay the basis for the generalization and normalization of a law of violence.

Phase I of the genealogy - the postwar phase associated with interstate cooperation, war crimes trials, and sanctions-reflects an energized internationalized transitional justice and related international aims and purposes. However, this phase would end soon after World War II as the exceptional postwar political conditions began to fade. In other words, the first phase of transitional justice was a product of postwar political conditions that were sui generis and would not recur in the same manner. ${ }^{5}$ With the Cold War and its balance of power came a related political equilibrium and an impasse for transitional justice. Nevertheless, the postwar legacy criminalizing state-sponsored wrongdoing as part of a universal rights scheme had unprecedented force-a legacy thought today to have formed the basis of modern human rights law. ${ }^{6}$ While current phenomena appear to be sharing certain dimensions with this earlier postwar period, there are important differences which are addressed below in Part II. ${ }^{7}$

Phase II is associated with a wave of accelerated democratization. Towards the end of the twentieth century, the Soviet Union's collapse and disintegration helped to lead to concurrent political transitions processes in diverse regimes. Withdrawal of Soviet-supported guerrilla forces in the late 1970s accelerated the end of military rule and accompanying transitions in South America. These transitions were rapidly followed by post1989 transitions in Eastern Europe, Africa, and Central America. While these are often described as isolated developments, many of these conflicts had been supported by international power politics. Therefore, the end of the Cold War advanced their resolution and facilitated liberalization in the regions.

While the post-Cold War wave of transition raised the theoretical possibility of a return to the Phase I internationalism, as this article elaborates infra, these developments took their own form, one that moved beyond internationalism to global transitional justice. The form of transitional justice that emerged in this phase is associated with not only the rise of nation-building but also, as is elaborated infra, other more complex and

5. See Peter Merkl, The Origin of the West German Republic (1963).

6. Louis Henkin, The Age of Rights 1 (1990).

7. See infra text accompanying notes $8-10$. 
sometimes competing aims. Accordingly, the Phase II transitional model tends to rely upon more diverse rule-of-law understandings tied to particular political communities and local conditions. Instances of local or even privatized justice often stand in tension with a broader conception of justice associated with transnational politics.

By the twentieth century's end, there emerges what I contend is a third, "steady-state" phase of transitional justice. Phase III reflects the particularities of the post-Cold War framing. At this time, transitional justice is characterized by the fin de siecle acceleration of transitional justice phenomena associated with globalization, typified by conditions of heightened political instability, fragmentation, and persistent conflict. At this point, transitional justice moves from the exception to the norm, constituting a new paradigm of the rule of law. In the contemporary phase, transitional jurisprudence reflects the normalization of an expanded juridicized discourse of humanitarian law associated with pervasive conflict. Moreover, the available sources of legitimacy comprehend a continuum between the local and the transnational.

The contemporary episodes in transitional justice discussed here, the trials of Slobodan Milošević and Saddam Hussein, illustrate instances of Phase III transitional justice-seeking of responses associated with postCold War global politics. As instances of global transitional justice, these processes are transnational and play to more than one audience and constituency. Relatedly, these processes are aimed at advancing multiple political aims in a highly politicized context of persistent conflict circumstances as discussed below.

\section{Contemporary Transitional Justice: Milošević and Hussein Trials}

Let us now consider the forms of transitional justice associated with the contemporary moment, the ongoing processes that are the subject of this article. This Part discusses salient features of the Milošević and Hussein trials briefly and then proposes several points about what might characterize the contemporary phase in global transitional justice: the puzzle of the association of the marked increase in juridicization and an expansion of the reach of law in international affairs, while often in conditions of persistent conflict. These changes in conditions are reflected in the new developments in international humanitarian law, which now reaches beyond international conflict to intrastate incidents that occur even in peacetime, extending in particular to such extreme offenses as crimes against humanity. Even where internally based, legal responses to these developments can prevent the prospect of destabilizing policies. ${ }^{8}$ Nevertheless, as will be discussed further on, contemporary legal responses do not necessarily express an unequivocal sense of a progressive rule of law. ${ }^{9}$ Instead, as will be elaborated infra, one might best understand this by drawing on prior theories on transitional justice that shed light on law's

8. See infra text accompanying notes 56-68.

9. See infra text accompanying notes 25-45. 
relationship to its political context and the contextualized meaning of the rule of law in these political circumstances. ${ }^{10}$

Global transitional justice as elaborated below implies an expanded legalism, while at the same time reflecting its trends of juridicization and decentralization in terms of jurisdictional sites-local and transnationalas well as new legitimacies based on a paradigm shift from state- to humancentered discourses in foreign affairs. As discussed infra, a threshold humanitarian standard emerges. Below, contemporary processes of transitional justice are identified and discussed, with an eye to analysis and elaboration of these alternative paradigms.

\section{A. From Nuremberg to The Hague}

With the trial of Milošević in The Hague, international war crimes trials returned to Europe for the first time since World War II in the genealogy of transitional justice. On its face, this development appears to present a return or cycling back to the postwar trials. Yet this may well be a surface resemblance. To what extent do contemporary developments represent a sign of a return to internationalism?

Revisiting the postwar trials from the present perspective sheds light on the meaning of internationalism in the genealogy of transitional justice. What becomes evident is that internationalism lacks a fixed meaning and that it is best understood within a hermeneutic, historical context. For example, seen from the present perspective, and infused by the inevitable comparison with the existing international criminal tribunals, Nuremberg, while reflecting an agreement of the four Allies, was ultimately not all that international. ${ }^{11}$ Moreover, without a final judgment and confrontation against Hitler, Nuremberg lacked the ultimate symbol of a top political leader in the dock. Seen in a historical light, there is some overstatement in the extent to which the postwar trials lay the basis for contemporary transitional justice.

Accordingly, in some regard, one might say that it is the contemporary Hague trial of Slobodan Milošević that is the landmark case constituting the first prosecution of a political leader in an international proceeding. At the International Criminal Tribunal for the former Yugoslavia (ICTY), Milošević sits in the dock, charged with war crimes, crimes against humanity and genocide. These offenses have been made subject to international jurisdiction, although some were committed domestically, reflecting radical developments in the construction of international criminal

10. See Teitel, supra note 2 , at 74 .

11. Compare the Nuremberg Charter with other contemporary charters, such as those of the ICTY and other creatures of the U.N. bodies, either Security Council, in the case of ad hoc tribunals, or the General Assembly, in the case of the International Criminal Court. See Charter of the International Military Tribunal, Aug. 8, 1945, 82 U.N.T.S. 280 [hereinafter the Nuremberg Charter]; Statute of the International Criminal Tribunal for the former Yugoslavia, May 25, 1993, 32 I.L.M. 1192, available at http://www.un. org/icty/basic/statut/statute.htm [hereinafter ICTY Statute]; Rome Statute of the International Criminal Court, July 17, 1998, 2187 U.N.T.S. 90, available at http://www.un. org/law/icc/statute/romefra.htm [hereinafter the Rome Statute]. 
jurisdiction. ${ }^{12}$

To fully situate the contemporary ICTY's project with a historical eye necessitates reflection on its political context of post-conflict justice and, in particular, recognition of the full military and political context of the time and its relation to the contemporary processes. Going back to its origins in the Balkans conflict, transitional justice's asserted goal was to restore peace. In the midst of the conflict, a U.N. Security Councilappointed commission of experts investigated atrocities committed in the region and concluded, inter alia, that there had been willful killing, organized massacres, torture, and rape. Moreover, the determination was made to set up a court which assertedly would help restore peace in the midst of political conflict. ${ }^{13}$

Of course, this account raises many questions, for, after all, in the absence of a clear military victory, what exactly is the role contemplated for international criminal justice? As shall become evident, in these conflictive circumstances, transitional justice is denoted by difficult dilemmas. In such conditions, even more than in ordinary transitional justice, there is an overly ambitious aim for the role of the law: justice-seeking in the absence of peace. At Nuremberg, building on the historical "just war" trials tradition, victors' justice was meted out over a defeated enemy in its vanquished country. At The Hague, however, this is simply not the case. The recourse to an international tribunal remains distant from the Balkan conflict, and justice was being meted out in the midst of political conflict. From the start, it was evident that, in the absence of full authority, there would be some compromise in the potential for the law and a lack of full legitimacy. For example, the ICTY often lacks custody over the accused as well as control over the evidence. Even after a decade, those most responsible for war crimes, such as Radovan Karadžić and General Ratko Mladić, remain at large. ${ }^{14}$ Contrary to the mid-century postwar processes, in the contemporary setting, international justice bears a different relationship to political power. In the contemporary international tribunals, law bears a distinct relation to the exercise of military force and international intervention.

Therefore, a genealogical perspective necessitates thinking about these ICTY proceedings over a political time line. In this regard, one might consider the ICTY to have recently entered the latter stage of its proceedings. By 2008 , it must wrap up all trials. ${ }^{15}$ Indeed, at this point, one might

12. Milošević first appeared before the ICTY on July 3, 2001. Prosecutor v. Milosevic, Case No. IT-02-54, Initial Appearance (July 3, 2001).

13. See Report of the Security Council Mission Established Pursuant to Resolution 819, addressed to the President of the Security Council, U.N. Doc. S/25700 (Apr. 30, 1993).

14. See Press Release, Human Rights Watch, Bosnia: Arrest of Srebrenica Indictee Hailed, Karadzic, Mladic Still At Large (Apr. 17, 2001), http://hrw.org/english/docs/ 2001/04/17/bosher171.htm.

15. See Press Release, U.S. Dept. of State, Minikes: US Supports Completion Strategy for War Crimes Tribunals, Says ICTY Plays Important Role in Moving Balkans Towards Euro-Atlantic Integration (Nov. 5, 2003), http://usinfo.state.gov/dhr/Archive/2003/ Nov/06-767701.html. 
distinguish between the strategy used at the ICTY's inception and the "exit strategy" of the present stage. Earlier, the pivotal issues concerning the international tribunal at The Hague centered on the parameters for the bases for the assumption of international jurisdiction. Whereas at the present stage, it is just the reverse: the relevant questions explicitly concern the jurisdiction's future devolution and what ought to be the normative relationship of the international legal regime to that of the relevant states. As will be seen, these questions about what ought to be the normative relation of the international to the national turn out to be endemic to Phase III, the phase of transitional justice which is associated with an emerging global rule of law.

\section{B. Transitional Justice in the Iraqi Occupation}

While the political and military context associated with the Balkan conflict spurred the move to international justice, in Iraq, even in similarly conflictive circumstances, there was a different move. Rather than recurring to an international forum, the trials in Iraq instead illustrate successor justice in the context of an ongoing military occupation. ${ }^{16}$ While the initial attempts would later be abandoned in light of the security issues of the ongoing insurgency, ${ }^{17}$ the contemporary Iraqi trials give the appearance of continuing to be closely associated with a politics of occupation.

From the beginning in postwar Iraq, tragic mistakes were made in what can now be seen as miscarriages of transitional justice. ${ }^{18}$ The instant efforts at transitional criminal justice were preceded by attempts at deracinated constitutionalism: atomistic trials, radical purges, and compromised elections. In particular, there was a rush to debaathification, resulting in the evisceration of existing institutions, such as the Iraqi parliament and army. ${ }^{19}$ These purges needlessly sacrificed potential sources of legitimacy concerning, for example, ongoing constitutional reform at the time. In transitions there is often a problem of how to deal with prior regime institutions, given the mix of individual and collective responsibilities associated with systemic persecution, and this dilemma poses a challenge to the parameters of transitional reforms of the police and military. The postinvasion rush to debaathification involving speedy purges of the military and the police, arguably sacrificed present security to the claims of justice, leaving the country with a real military and security vacuum. Yet, subsequently, this first response was revisited, and a new view emerged regard-

16. Though there was a substantive debate over what ought to be the site of the trial, see infra text accompanying note 78 .

17. See Michael P. Scharf, Can This Man Get a Fair Trial?, WASH. Post, Dec. 19, 2004 , at B1.

18. See generally Larry Diamond, Squandered Victory: The American Occupation and the Bugled EFfort to Bring Democracy to IraQ (2005).

19. See Peter Slevin \& Rajiv Chandrasekaran, Iraq's Baath Party Is Abolished; Franks Declares End of Hussein's Apparatus as Some Members Retake Posts, WAsH. Post, May 12, 2003, at A10 (noting that debaathification was a goal of U.S. authorities during the occupation period). 
ing the Iraqi army's capacity for democratic transformation. ${ }^{20}$

The failure of sweeping debaathification spurred a turn away from the bureaucratic responses to the past regime, in part, to the individualized response characterizing criminal justice. This move to criminal justice opened up a vigorous debate over what authority ought be exercised over Saddam Hussein and, in particular, whether it ought to be national or international. While these questions reflect competing rule of law values, the waging of this debate at this time clearly reflects Phase III of transitional justice characterized by globalization.

The association of justice processes with the U.S. occupation raises issues as to the extent to which these trials can advance the purposes of the transition. The day of the purported withdrawal from Iraq also launched the first trial of Saddam Hussein. ${ }^{21}$ At the time, the exhortation to justice had an air of Thermidor. With the former top leadership in custody, including Hussein, there was an imminent threat that heads would roll. Though this plan would be abandoned, given the then ongoing level of American control, the first trial would have been neither national nor international, but an "occupation tribunal," with consequences for its legitimacy and potential for contributing to the rule of law. ${ }^{22}$ In any event, the selection of judges by what was widely viewed as a wing of the occupation, as well as the role of the United States in the 1980's, would seem to make the Iraqi case equally vulnerable to the claim to victor's justice. ${ }^{23}$ Indeed, given the ongoing occupation status, the establishment of a state trial policy would seem to be a symbol of Iraqi sovereignty. While such dilemmas are common to pre-transitional periods, contemporary Iraqi prosecutions pose an extraordinary and acute lack of security. ${ }^{24}$

Part II's discussion of the political context and mandates of both the ICTY and the Iraqi Special Tribunal (IST) becomes relevant to the argument elaborated in Part III regarding the character and form of transitional justice developments associated with this political moment. There are clear analogies with these trials that relate to the context of victor's justice and to the ambitious aims of democratization, peace and reconciliation.

\section{Global Transitional Justice: Comparative Perspectives}

This Part introduces what is termed here as Phase III "global transitional justice." Transitional justice in the Balkans and Iraq offers two instances of what this article characterizes as global transitional justice. This Part endeavors to situate these two trial processes in a political con-

20. See Bradley Graham \& Peter Baker, Deadline for Troop Withdrawal Ruled Out, Wash. POST, Jan. 30, 2005, at Al.

21. See Peter Landesman, Who v. Saddam?, N.Y. Times MAG., July 11, 2004, at 34

22. See Ken Roth, War in Iraq: Not a Humanitarian Intervention, in HuMAN RigHTS WATCH WORLD RePORT 2004, at 13, available at http://hrw.org/wr2k4/download/wr 2k4.pdf.

23. See John F. Burns, Hussein Tribunal Shaken by Chalabi's Bid to Replace Staff, N.Y. Times, July 20, 2005, at A9.

24. Roth, supra note 22 . 
text in the immediate aftermath of conflict and the pursuit of a related mix of aims relating to both local and global, to post-conflict justice, to nationbuilding, and to the establishment of the rule of law. Despite their differences, consideration of this shared context enables comparative analysis.

Below, the article elaborates and analyzes issues concerning the diverse aims of contemporary transitional justice. The discussion is divided into four parts: first, transitional justice and normative regime change; second, issues posed by globalizing transitional justice; third, transitional justice for peace; and lastly, transitional justice's relation to the historical just war aims.

\section{A. Transitional Justice and Regime Change}

Genealogical inquiry reflects the course in transitional justice over time and the particular aims associated with different periods of political transformation. As suggested earlier, the contemporary period reflects a chastened commitment to deep political change and the limitation of goals to post-conflict restoration of peace. ${ }^{25}$ This mix of purposes, as is elaborated infra, may well not be necessarily fully reconcilable, which may well help explain the perception of the ways they seem to pose instances of imperfect transitional justice.

In this regard, transitional justice at present reflects a distinctive conception associated with the period of post-Cold War political change. Because of the political context of the current trials and their aim of justiceseeking amidst conditions of conflict, the onerous burden of creating a visible normative shift depends upon transitional justice. Where criminal justice is brought to bear from outside the state, one aim is to jumpstart political transition processes on the ground.

Both trials discussed in this article aim to draw a line for the future. Yet, how can some sense of legitimacy be achieved in the transition? Where would it come from? Vivid construction of transition should be achieved by drawing a clear line distinguishing the past from the present. Can these contemporary trials express a clear message in this regard?

In current political conditions, any pursuit of justice goes to the very possibility of a global rule of law. This article pursues a genealogical structure of transitional justice and discusses current responses within a postCold War framework. What sort of rule of law do the current trials represent? To some extent, the message is incoherent because of the complexity and the scope of the sought-for normative change in terms of wartime justice, nation-building and post-conflict justice. Implemented in the midst of conflict, these trials are aimed at jumpstarting the political transition. In the absence of a more established matrix of rule of law, however,

25. There are scholars who emphasize the didactic goals of the Miloševic trial. See Martti Koskenniemi, Between Impunity and Show Trials, 6 Max PlanCK Y.B. OF U.N. LaW 1 (2002). But recognizing the expressive and didactic purposes raise a separate question about the substance of the message, i.e. a trial that establishes the truth about facts in controversy seeks to be after lessons in what? This article contends there have been ongoing changes in these processes' political purposes. 
transitional justice here bears a heavy and complex burden. Indeed, the difficulties in the current administration of transitional justice reflect some of the dilemmas of justice-seeking processes in strained political conditions.

The overall normative aim of drawing a line of legitimacy between regimes is evident in the apparent interchangeability of transitional justice's various forms. For example, in Iraq, there was a debate about diverse modalities, whereby various transitional responses were proposed and abandoned in short order, reflecting the problem of sequencing in situations of diminished legitimacy. Which responses should come first? To what extent ought constitutions precede or follow elections? The persistence of these debates suggests a surface interchangeability in the modalities, concentrating on a largely symbolic modicum of transitional justice. It also suggests that there can be no fixed rule and that the right modality will depend upon which institutions and processes can best advance legitimacy in the particular political and juridical conditions at stake.

From the start, the proposed sequence began with trials, followed by constitution drafting and elections. Following political resistance, this proposal was abandoned and a change of sequence ensued: elections preceding trials, and constitutionalism thereafter. ${ }^{26}$ As with the constitutional project, the first impulse was to have early trials of Saddam Hussein and his henchmen. Postponement of the trials was welcome news because, at the time, given their lack of expertise in war crimes, the Iraqi judiciary could not handle such high profile war crimes trials, and the United Nations would not bail them out. ${ }^{27}$ Other good reasons existed to slow down the wheels of justice. Although the trials were postponed, the proposed timing reflects the purpose to link up the trials to the electoral transition. Criminal justice was aimed at promoting the political transition, that is, to underscore the illegitimacy of the prior regime and to advance political transformation.

Nevertheless, the question remains whether transitional justice can foster normative regime change in these political and juridical conditions. The ICTY offers a cautionary tale. By some measures, these international proceedings appear to have backfired by producing a nationalist backlash. The Hague tribunal's indictment has hardly affected the political standing of Milošević who was lured out of the country under false pretenses. By contrast, the political leader who openly cooperated with the tribunal, late Prime Minister Zoran Đinđić, paid for it with his life. Recent Serbian elections turned into something of a referendum on Milošević. ${ }^{28}$ Within this

26. See Ruti Teitel, Operation Iraqi Freedom: Just or Unjust War? Humanitarian Action, or Simply Geopolitics?, FindLaw, Apr. 8, 2003, http://writ.news.findlaw.com/ commentary/20030408_teitel.html; Iraq Self-Rule, ONLiNe NEwsHour, Nov. 13, 2003, http://www.pbs.org/newshour/bb/middle_east/july-dec03/iraq_11-13.html.

27. See Warren Hoge, U.S. and U.N. Are Once Again the Odd Couple Over Iraq, N.Y. Times, Nov. 14, 2004, at Al5.

28. See Bogdan Ivanisevic, Softly-Softly Approach on War Crimes Doesn't Help Democracy in Serbia, Human Rights WATCH COMMENTARY, http://hrw.org/english/docs/2004/ 06/25/serbia8966.htm (last visited July 30, 2005). 
society, there continues to be extensive denial of the basic facts of the atrocities committed during the conflict. ${ }^{29}$

\section{B. Contemporary Transitional Justice and the Legalist Paradigm}

This Part discusses the contemporary understanding of legalism by evaluating the two trial processes discussed in this article as examples of alternative international and national legal models, and their potential contribution to the rule of law.

Postwar scholars, such as Judith Shklar, supported the international criminal tribunal at Nuremberg and the international law upon which it was predicated for their contribution to legalism. ${ }^{30}$ In the postwar context, in light of the problems of Nazi law, the turn to international law made a contribution to the perception of the reestablishment of legality in Germany, ${ }^{31}$ although scholars are divided on the extent to which the postwar trials ultimately contributed to the restoration of the rule of law. ${ }^{32}$

However, consider at this juncture whether international law is too facilely equated with legality. To what extent, ultimately, does it advance the rule of law domestically? In the postwar context, scholars were sober about the law's potential and characterized legality as a "continuum," a "matter of degree." 33 Therefore, political context is extremely important, and accordingly, one might expect that it is precisely in the associated postwar context that international law can make a contribution to the establishment of the rule of law. Were we to analyze the contemporary scene from the postwar perspective, therefore, the degree of legalism in the trials would be of relevance, as well as its potential impact on local politics, i.e. the relative contributions to the rule of law in these circumstances.

In this regard, the two processes discussed here, the ICTY at The Hague and the prospective Baghdad court, with their differences, reflect varying dimensions of legalism's potential as well as its limits. Thus, for example, in the midst of the Balkan conflict, the turn to an international tribunal offered important elements of the rule of law. ${ }^{34}$ The turn to international law offers continuity in the enforcement of equal protection and adherence to individual accountability under the law. There are other more particular values expressed in prosecutions of war crimes and crimes against humanity charges as discussed infra.

Nevertheless, the Milošević trial also demonstrates the limits of legalism. As the trial drags on, the inevitable analogies to the Nuremberg trials

29. See Nicholas Wood, Video of Serbs in Srebrenica Massacre Leads to Arrests, N.Y. Times, June 3, 2005, at A3.

30. See generally Judith N. Shklar, Legalism: Law, Morals, and Political Trials (1964).

31. Id. at 156. For Hannah Arendt, the international component was important for its symbolism.

32. See Jeffrey Olick, In the House of the Hangman: The Agonies of German DEFEAT, 1943-1949 (2005).

33. SHKLAR, supra note 30.

34. For discussion of international law's potential for contribution to rule-of-law values, see TeITEl, supra note 1 , at 20-21. 
wear thin. ${ }^{35}$ While the Nazi.Reich's top rung was convicted in a matter of months, those proceedings might well be considered to have occurred in conditions of diminished legalism. By contrast, at The Hague, one might conclude there to be an apparent surfeit of procedure and regulation.

Turning legalism on its head, Milošević has taken advantage of the process by insisting on representing himself, delaying the trial and chatlenging the tribunal's jurisdiction and legitimacy. ${ }^{36}$ The longer his self "defense" continues, ${ }^{37}$ the more successful Milošević will be in portraying himself as less a perpetrator than a "victim" of the international community and its legal processes. This strategy appears to have been effective in undermining the trial's effects in condemning perpetrators of the most heinous offenses at the top of the state power echelon.

From the start, the proposed trial of Saddam in the specially established IST reflected a lesser commitment to legalism. ${ }^{38}$ To the extent that the IST exhibits procedural irregularities, negative consequences will follow for the trial's capacity to lay the foundation for the rule of law in postconflict Iraq. From the process's inception, there has been a host of rule of law problems concerning such factors as the newly established court, underlying charter, the appearance of discontinuity and selectivity, and arbitrariness in the law. Other issues go to due process, transparency and fair defense. The first public glimpse of Hussein as an unrepresented defendant, however distorted, laid a basis for victimization. As in the Milošević trial, inadequate representation could hardly send a message of the reestablishment of rule of law in Iraq. ${ }^{39}$ Issues of due process, access necessary to a fair defense, and transparency persist. ${ }^{40}$ So far, the trial process has not been open; rather, it reflects attempts to control the handover and related processes.

There is also the likely problem of proof. While there is no lack of documentation, particularly of the worst of the offenses, such as genocide, difficulties arise in linking the proof up to the actions of senior officials, thereby establishing the "chain of command." As with Milošević, it may be difficult to link the atrocities directly up to Saddam's policies. ${ }^{41}$ Ultimately, this may not matter because the burden of proof in the Iraqi tribunal is not explicitly necessarily the usual high standard, as nothing in the

35. At the time of this writing, the proceedings are into their fourth year.

36. lan Traynor, Milosevic Trial Falters After Judge Retires, The Guardian (London), Feb. 24, 2004, at 17.

37. His defense also relied on frequent claims to illness, also building the victim role. See id.

38. See Statute of the Iraqi Special Tribunal, Dec. 10, 2003, 43 I.L.M. 231, available at http://iraq-ist.org/en/about/statute.htm [hereinafter The IST Statute].

39. William Langewiesche, Ziad for the Defense, 295 The ATLANtic Monthly 65 (2005), available at http://www.theatlantic.com/doc/prem/200506/langewiesche.

40. See Anthony Dworkin, Saddam Hussein and Iraq's War Crimes Iribunal, Crimes OF WAR ProjeCt, Dec. 21, 2003, http://www.crimesofwar.org/onnews/news-saddaml. html.

41. See Human Rights Watch, Iraq: State of the Evidence, 16 Human Rights Watch REPORT No. 7(E), 5 (2004), available at http://hrw.org/reports/2004/iraql 104/iraq 1104.pdf. 
statute or rules demands a burden of proof "beyond a reasonable doubt" ordinarily associated with the application of the rule of law in modern criminal justice. ${ }^{42}$ Yet, applying a lower standard will once again backfire as to the uses of the trial to establish legitimacy and the rule of law in Iraq. Finally, there is a related problem due to the passage of time and its relation to establishing the proof of the atrocities. Many of the Hussein trial's central charges relate to offenses perpetrated against civilian opposition going back for years. ${ }^{43}$ These may well prove difficult to document as they go back two decades. ${ }^{44}$

Yet; to whatever extent there are departures from due process, such a trial strategy is not likely to advance the rule of law or show change toward liberalization. The dilemmas raised here over the form of justice have been recurrent in transitions, frequently resulting in what I have termed the "limiting of the criminal sanction" as such dilemmas effectively limit the use of criminal justice in periods of transition. ${ }^{45}$ These persistent dilemmas occasioned by criminal justice in transitional circumstances reflect issues about whether this form of justice can help advance the current regime's legitimacy.

\section{Globalizing Justice: Transcending Old Dichotomies}

During the last century, the central point of reference in the conceptualization of the shape and role of international rule of law was constituted by the international-national dichotomy. At present, an evident remapping of public international law is afoot. A new paradigm has emerged whose dimensions refer to expanded legalism, while at the same time also predicated upon fragmentation, proliferation and multiplicity of jurisdictional sites - national, international, and transnational-and attendant new legitimacies.

In the present post-Cold War context, there is an evident transformation in the significance of the expanded international criminal justice. Clearly, international criminal justice's aims and contributions are mixed, as justice-seeking in such new political circumstances inevitably implies diverse understandings of rule-of-law values. To begin, consider the extent to which international law at The Hague affords the rule-of-law values of fairness and neutrality, which one might juxtapose to other rule-of-law dimensions privileging local accountability. This breakdown in respect for rule-of-law values has historical resonance. For example, over much of its history, the United States has long emphasized popular sovereignty, local accountability, and, therefore, national over international law and its processes. Relatedly, at present, the United States (and most Iraqis) favors a nation-building model, where transitional justice is intended to serve

42. See The IST Statute, supra note 38.

43. The IST Statute states that wherever there are gaps, there ought to be reversion to existing Iraqi criminal law, but there is nothing in the statute regarding what standard to apply for the burden of proof. See id. art. 16 .

44. See Human Rights Watch, supra note 41.

45. Teitel, supra note 1 , at 28. 
local accountability and related purposes. By contrast, Europeans and the human rights community have tended to prefer multilateralism and to advocate U.N.-affiliated trials, such as those convened at The Hague to adjudicate atrocities in the Balkans and Rwanda, largely on the basis of privileging other rule-of-law values such as neutrality. Multiple rule-of-law rules serve the varying aims of transitional societies in global politics, while transitional conditions often exacerbate tension in adherence to these diverse rule-of-law values.

To some extent, the contemporary Milošević and Hussein proceedings reflect the varying dimensions of legality discussed above. One might even regard these two contemporary processes as mirror images of the international-national law dichotomy. Nevertheless, this article suggests that, to some degree, the dichotomy is overstated because what is frequently at stake in transition is a core rule-of-law dilemma which cuts across both the local and the international legal systems, though in each instance affecting different rule-of-law values. ${ }^{46}$

From its inception, transitional justice in Iraq raised profound dilemmas: to what extent could the trial of Saddam offer the sought-for restoration of the rule of law? What body, if any, had the legitimacy to sit in judgment? Should this be a domestic prosecution convened in Iraq; an international adjudication presided over by a foreign judiciary as in the cases of Nuremberg, the ICTY, and Rwanda; or, alternatively, a "mixed" or "hybrid" tribunal, like those convened in Sierra Leone and East Timor?"7

The choices were hardly clear cut, with each jurisdictional scenario tied to a nexus which arguably fulfills different rule-of-law values. The international approach would afford a modicum of legal continuity through the International Criminal Court (ICC) and its charter, reflecting an apparent international penal code. This alternative legal system appeals to values of fairness and neutrality, while the mechanisms of national justice afford local accountability. ${ }^{48}$ Accordingly, each jurisdiction advances important but often competing rule-of-law values. Whatever the ultimate form of the Baghdad tribunal, it will be distinguishable from the posture of the Hague tribunal, or, the historical postwar context of the Allies' "total" sovereignty.

Moreover, in present global politics, to what extent can one consider the international and national legal conceptions as neatly divisible? While the structure of these transitional justice debates commonly presumes an ongoing formalism and related dualism in the law, seen from a genealogi-

46. Id. at $11-12$.

47. For instances of hybrid trials and discussion of their advantages in advancing transitional rule of law, see Statute of the Special Court for Sierra Leone, available at http://www.sc-sl.org/scsl-statute.html (last visited July 30, 2005); Jack Snyder \& Leslie Vinjamuri, Trials and Errors: Principle and Pragmatism in Strategies of International Justice, 28 INT'L SEC. 5, 20-30 (2003).

48. For discussion of the potential of diverse judicial legal systems for their connection to the advancement of the establishment of the rule of law, see Paul Kahn, Independence and Responsibility in the Judicial Role, in Transition to Democracy IN LATIN America: The Role of the Judiciary 73-87 (Irwin P. Stotzky ed., 1993). 
cal analysis, this view appears to be anachronistic. At this juncture, there are experiments in the realignment of the national-international balance and in new hybridizations associated with global rule of law. These developments in international criminal law and its reception pose a challenge which penetrates domestic legal systems and their institutions.

\section{From the International to the Global: From Primacy to Complementarity}

The contemporary phase of transitional justice characterized here as "global" is linked up to a changing relationship of the state to the international, in both its political and legal dimensions. New guiding principles apt for global politics, this article contends and as is elaborated below, are now overtaking the prevailing understanding of the relation of international to national justice whereby it plays a sustained threshold role.

For some time, there has been a clear assumption about the superior relation of international to national law. While there are differences among states regarding the internal status and weight of international law, ${ }^{49}$ one might say that a hierarchic top-down understanding of jurisdiction well defines the twentieth century view of the state within the international legal system. Yet, at Nuremberg, this assumption regarding the juridical relationship was not explicitly spelled out because the exceptional political circumstances at the time did not present the usual status and relation of the state in international realm but, rather, involved a conceded absence of national sovereignty. Although the Nuremberg tribunal did contemplate follow-up trials, ${ }^{50}$ they would not occur in Germany until the state had recovered its political and juridical sovereignty. While this was the understanding at Nuremberg, the question of the international tribunal's jurisdiction-especially over violations committed against the state's own citizens-was jurisdictionally the most controversial element that went to the heart of the postwar trials, particularly in the understanding of its legacy over time. For prudential reasons, the tribunal would end up limiting itself to those crimes against citizens associated with the waging of war, linking crimes against humanity up to more traditional, long-established war crimes. ${ }^{51}$ This judicial self-limiting highlights the perceived vulnerabilities in the court's arrogation of authority over the state in the international realm. And, it would also illustrate the struggle to reconcile the universal aspirations of the law with the more particularist politics on the ground.

49. On monist and dualist systems, see J. H. H. Weiler, The Transformation of Europe, 100 Yale L.J. 2403, 2413-15 (1991); see also Curtis A. Bradley, Breard, Our Dualist Constitution, and the Internationalist Conception, 51 STAN. L. REV. 529, 530-31 (1999).

50. For a bibliography of war crimes trials, see WAR CRIMES, WAR CRIMINALS, AND War Crimes Trials: An AnNotated Bibliography and Source Book (Norman E. Tuterow ed., 1986).

51. See Telford Taylor, The Anatomy of the Nuremberg Trials: A Personal MemOIR 583 (1992). 
For about a half century, the postwar trials discussed above would remain solitary precedents in international criminal adjudication. Indeed, the ad hoc tribunals of the last decade concerning the Balkans and Rwanda articulate the unspoken assumptions at Nuremberg about the international-national legal relations. These tribunals' charters spell out that the relation of international and national law is clearly one of "primacy" in a hierarchical structure. ${ }^{52}$

Contemporary global legalism, however, redefines the status and relation of the international to the national legal regimes in two major ways. First, in the contemporary moment, international criminal law is more pervasive, extending beyond the international realm and state borders as well as circumstances of conflict. Second, while international law is more pervasive and has greater reach than before, it is also increasingly defined by its ongoing interstitiality. By interstitiality it is meant here that in the contemporary relation of the international to the national, international criminal law operates not as an exceptional matter associated with extraordinary postwar sovereignty, but instead in a regular permanent way. These radically transformed circumstances for international criminal justice, both in scope and reach, beg the question of what is to be the relation of international to domestic law in the area of criminal justice. The transformed international system demands a guiding principle apt to address the ongoing relationship of the multiple legal regimes.

Such a principle exists, and this article articulates what at present may well be implied in the legal changes in the jurisdiction of the ICC, the first permanent international criminal judicial body. For the ICC is predicated upon an alternative jurisdictional principle to primacy, stated under the reconciling principle of "complementarity." 53 In the words of the Rome Statute, the ICC's jurisdiction is triggered if, and only if, the national legal system is "either unwilling or unable" to exercise jurisdiction. These conditions will need to be interpreted, but as prefatory to the ICC's substantive adjudicatory work, this evaluatory enterprise is already a substantial element of the work of the tribunal. ${ }^{54}$ Indeed, according to the "complementarity" principle, when countries lack working legal systems for even minimal criminal justice, these international law institutions and processes will lay a floor. Ultimately, this jurisdictional principle goes beyond the procedural to the substantive to construct a global legal minimum which, insofar as it relates to the most heinous crimes, largely takes the form of a radical expansion of international humanitarian law. 55

\section{E. Universality's Law}

Beyond the idea of global complementarity discussed above, other normative understandings have emerged in Phase III of transitional justice. While the above subpart elaborates how the traditional antinomies of the

52. See, e.g., ICTY Statute, supra note 11 , art. 9.

53. Rome Statute, supra note 11 , art. 1 .

54. See id. pt. 2 ("Jurisdiction, Admissibility and Applicable Law").

55. Id. art. $\mathrm{l}$. 
relationship of international to national law are transcended in and by the idea of complementarity, there are other mediating constructs in contemporary transitional justice, such as the concept of the law of humanity. The ascendance of this area of human rights law reflects the changes in law's potential in present global politics. ${ }^{56}$

These normative understandings are raised in the instant processes of Milošević and Hussein in the relevant charges. In substance, the law of humanity implicates the most serious offenses which transcend national borders and have come to be known as having "universal" jurisdiction. The concept of universality, as we will see, offers a basis for reconciling aspects of the local and the international in the contemporary global legal system.

For some time, crimes against humanity have captured the imagination in writing on transitional justice. Let us consider why. Judith Shklar conceived of the postwar trials' legitimacy as depending on the charge of crimes against humanity: "[A]s far as the trial concerned itself with crimes against humanity it was both necessary and wise." 57 In the epilogue to her book Eichmann in Jerusalem, Hannah Arendt contends that the "offense against humanity" formed the basis of the postwar trials. ${ }^{58}$ It was the mass murder of the German Jews that laid the foundations of the charge of crimes against "humanity." While these scholars wrote of trials involving both international and national processes, respectively, no matter: crimes against humanity are the offense par excellence that defined the postwar trials as transcending an exercise in political justice but as a statement regarding the protection of humanity.

Consider how crimes against humanity express the core rule-of-law norm that there is no escaping humanitarian law's protective force. The core legality values of equality and general applicability of the law are expressed in two dimensions of the crime against humanity. First, the offense defines and condemns the persecution of "any" citizen group and therefore, is equally applicable to any citizen regardless of nationality, ethnicity or religion. 59 Second, insofar as these charges may involve abuse of power by political leaders, no one, even acting leaders, is immune from judgment. As such, the offense of the crime against humanity goes to the very basis of a core rule-of-law regime.

This rule-of-law message is also seen in the extent to which current human rights law emphasizes crimes against humanity's universality. Prosecution of crimes against humanity appears to instantiate a universal norm because, by definition, such crimes offend the entire community of

56. Ruti Teitel, Humanity's Law: Rule of Law for the New Global Politics, 35 Cornell INT'L L.J. 355, 370-73 (2002).

57. SHKLAR, supra note 30 , at 155 .

58. Hannah Arendt, Eichmann in Jerusalem: A Report on the Banality of Evil 258 (1994).

59. For the first positive definition of crimes against humanity, see Nuremberg Charter, supra note 11, art. 6(c); ICTY Statute, supra note 11, art. 5; Rome Statute, supra note 11 , art. 7. 
"humanity" and therefore subject to universal jurisdiction. Moreover, because such offenses may be committed anywhere under any circumstances, whether during war or in peacetime, they may be subject to transnational adjudications and prosecution by any state as a matter of universal concern. ${ }^{60}$ Despite this idealistic view, however, there are always political constraints.

One might consider, both at The Hague and in Baghdad, the extent to which crimes against humanity lay the basis for the trials' ultimate claim to legitimacy. Consider the aims of the contemporary adjudications under the law of humanity and the application of universal jurisdiction in global transitional justice. One of contemporary transitional justice's goals is nation-building, and trials are commonly thought to assist in defining a community in the state consolidation process. However, where the crime adjudicated is defined as one against humanity, what is the relevant community? To what extent do such trials assist in nation-building? Some of these questions arose before, in the postwar successor trials. ${ }^{61}$ Moreover, as prosecutions of leaders for acts committed against their own citizens, both trials discussed here challenge the traditional understandings of territoriality and sovereignty. Therefore, what aims do such trials accomplish? The association of these trials with present politics alludes to their potential role in spurring political regime change in current global circumstances.

Despite their broad reach, there are ways that the charges of crimes against humanity may miss a critical point of the trials. Consider to what extent these offenses can capture the masterminds of repressive policies. After all, the instant proceedings differ from other historic successor trials. Milošević and Hussein are no Eichmann. As their countries' top political leaders, they are no cogs in the wheel, and their offenses form part and parcel of the promulgation of the ideological policies involving aggressive nationalism and ethnic persecution.

Moreover, insofar as the contemporary charges go beyond crimes against humanity to include war crimes, the trials risk politicization. Particularly, in the Milošević trial, prosecuting war crimes raises broader questions concerning the legality of the NATO intervention at the time of the indictment. Moreover, other issues raised by the reliance on the "joint enterprise" theory may well make it harder to hold Milošević individually responsible for genocide and crimes against humanity. ${ }^{62}$

Given the mix of aims served by transitional justice in this context, one might question whether and to what extent conducting crimes against

60. See David Luban, A Theory of Crimes Against Humanity, 29 Yale J. INT'L L. 85, 124-131 (2004) (contending for the nexus between the offense against humanity and universal jurisdiction); see also Stefaan Smis \& Kim Van der Borght, Belgium: Act Concerning the Punishment of Grave Breaches of International Humanitarian Law, 38 INT'L LEG. MAT. 918 (1999).

61. See ARENDT, supra note 58, at 269 (arguing for an international tribunal to adjudicate crimes against humanity).

62. See Rome Statute, supra note 11 . 
humanity prosecutions in international fora can assist the advancement of nation-building. ${ }^{63}$ In some ways, this raises the flip side of the national successor trials convened over recent decades. When they are conducted in pursuit of the aim of political transition, prosecution of crimes against humanity expresses a core equality under the law norm and, therefore, can advance an important element of reestablishing the sense of a threshold rule of law.

While there was an assumption of the nexus of trials to democratization and nation-building that was central to the project of postwar trials at mid-twentieth century, at present, signs indicate that contemporary international trials could well be generating a nationalist backlash which postwar scholars would have found unimaginable. ${ }^{64}$ As it also raises issues for the so-called "completion strategy," the backlash is likely deleterious for the trials' ultimate impact. When the tribunal closes its doors, where should its unfinished, remaining cases go? When Chief Prosecutor Del Ponte calls for "new partnerships for justice," what realistically are the choices? In this latter stage, can the ICTY's indictments be turned over to the national courts? Will the region's domestic judiciaries step up to the plate and extricate themselves from the surrounding fractious politics?

So far, the picture is not promising. The very few trials held in the region reflect pervasive ethnic bias. In all of Republica Srpska, to date, there has only been one war crimes prosecution involving a Bosnian Serb. ${ }^{65}$ The local judiciary seems so far to be unable to run fair trials without assistance. Were international assistance to be given, it could proceed along the distinct relation of the international to the national that characterizes Phase III of global transitional justice. Along the lines of the "complementarity" continuum, ultimately international law may well have a lesser role than a full tribunal but would nevertheless contribute a measure of legality by integrating the international into the local, either institutionally or, alternatively, through adding select personnel or embedding itself in local law. Yet, the legitimacy of this sort of legal nexus would depend on the recognition by the locals of the potential of such institutions and processes to advance the rule of law.

For the IST to advance its transitional aims, the attempt as much as possible is to focus on the substantive bases of jurisdiction so as to circumscribe potential countervailing challenges to the occupation. The more limited the scope of its jurisdiction, the greater the likelihood of success. ${ }^{66}$ It is clear, therefore, that there will be rule-of-law trade-offs. Broader war crimes charges, such as those involving Iraq's invasion of Kuwait, are likely

63. For critique of the view that punishment in the ICTR will advance transitional aims, see generally Jose Alvarez, Crimes of States/Crimes of Hate: Lessons from Rwanda, 24 Yale J. Int'l Law 365 (1999).

64. SHKLAR, supra note 30 , at 169.

65. Human Rights Watch, Justice at Risk: War Crimes Trials in Croatia, Bosnia and Herzegovina, and Serbia and Montenegro, 16 Human Rights Watch RePORT No. 7(D), 9 (2004), available at http://hrw.org/reports/2004/icty1004/icty1004.pdf.

66. John F. Burns, First Court Case of Hussein Stems from ' 82 Deaths, N.Y. TIMEs, June 6,2005 , at A1. 
to take away from the IST's jurisdiction over charges against Hussein and, worse yet, for present political purposes, potentially implicate the American alliance with Hussein in the 1980's. Moreover, for many Iraqis, this basis of substantive jurisdiction would not likely offer much of a source of legitimacy in the transition.

Contemporary political leaders' trials may well offer lessons on a number of issues, ranging from the problem of proof to the way the substance of the charges risk the trial's politicization. Accordingly, the focus of the Iraqi trials' subject matter jurisdiction needs to be upon crimes against humanity, that is, on what Hussein did to his own citizens, because this goes to the heart of the illegitimacy of the prior regime and, therefore, at least in part to the legitimacy of the occupation and the establishment of a successor regime. Even limiting jurisdiction to the relatively undisputed crimes against humanity charges, especially those concerning the Kurdish minority, while it would serve the purpose of inclusion at this delicate moment in the country's political transition, is likely to raise broader issues in the region. ${ }^{67}$ In his defense, perhaps absorbing the lessons of the Miloševic trial, Saddam may well challenge the United States with "tu quoque" defenses on the basis of its recent invasion as well as its broader historic role in the region. ${ }^{68}$ This could well risk the trial's potential contribution to establishing the legitimacy of the successor regime. It is clear that the many trade-offs raised by the convening of the trial of Saddam Hussein at this stage of the transition pose profound challenges to the trial's potential for contributing to the country's liberalization and establishing the rule of law.

Consider other aims of prosecuting crimes against humanity and related human rights violations in present global political circumstances. Beyond their role in the transition, they serve as a basis not only to do justice with respect to crimes committed in relation to the war, but also, as a form of post-conflict justice, to justify the initiation of war and the basis for military intervention. This conflictive and potentially contradictory dimension of present transitional punishment processes is taken up in the next part.

\section{Justice at War and for Peace}

The trial processes discussed here share a close association with and relation to conditions of conflict that raise distinct aims and purposes inextricably intermingled with relevant political circumstances. In this regard, these trials' transitional goals transcend their individual parameters and

67. See Human Rights Watch, Whatever Happened to the Iraqi Kurds? (1991), http://www.hrw.org/reports/199l/IRAQ913.htm.

68. Tu quoque, or the "dirty hands" strategy, has been used regularly by the defense in post-conflict trials to characterize the trials as politically motivated. Among others, Jacque Verges used this strategy against France in the trial of Nazi Chief in Lyons Klaus Barbie. See Richard Bernstein, Spirits Haunting a Belated Courtroom Reckoning, N.Y. TiMES, May 18, 1987, at A4; and Guyora Binder, Representing Nazism: Advocacy and Identity at the Trial of Klaus Barbie, 98 YALE L.J. 1321, 1357-58 (1989). 
differences. Both trials involve globalized conditions of conflict and distinct circumstances of justice that also shape the trials' purposes. Both trials operate not solely or even primarily for retribution but, rather, to effect change to end conflict and to bring about reconciliation. Yet, to what extent can war crimes trials help bring about peace and reconciliation? In circumstances of ongoing conflict, can the pursuit and even imposition of justice advance the aims of deterrence, peace and reconciliation? ${ }^{69}$

Pursuit of a genealogical approach here necessitates inquiry into the form of justice associated with present political conditions, which illustrates the normalization of Phase III transitional justice. Both the Milošević and Hussein trials exemplify instances of trials in the midst of ongoing conflict and assertedly convened to advance conciliatory purposes. In this regard, both The Hague and Baghdad reflect an extraordinary and difficult context of exercises of law, in the midst of conflict, for justice and peace. ${ }^{70}$ Perhaps, not surprisingly, the trials' aims are often contradictory and involve difficult trade-offs, which makes the message of these trials often ambivalent.

While modeled after Nuremberg, the Hague tribunal was established in distinctive political circumstances. While the post-World War II trials were seen by many as a form of victors' justice, the ICTY, convened in the midst of a bloody conflict, lacked an analogous authority. Its mandate was not merely to shape the meaning of a prevailing peace but, instead, to hold individuals to account for their acts in an effort to establish and promote peacemaking and reconciliation.

Consider the potential nexus between international criminal justice and peace. The question became to what extent could justice delivered in a courtroom in The Hague, isolated from the conflict on the ground, nevertheless contribute to peace in the region? While the ICTY's central mission was to transform the conflict in the Balkans to one of individual crimes answerable to the rule of law so as to achieve peace and reconciliation in the region, its efforts to accomplish this mission underscored the rule of law's dependence on a supportive matrix that is generally dependent on the vitality of both the international and the national legal systems.

The ICTY's double mission may well be compounding its difficulties as well as obscuring the public perception of its success. Since the tribunal

69. More and more, transitional criminal justice is said to be not in tension with reconciliation aims but, instead, itself a means toward reconciliation. See KadER AsMal, louise Asmal \& Ronald Suresh Roberts, Reconciliation Through Truth: A Reckoning of Apartheid's Criminal Governance (1996). For critical analysis, see Ruti Teitel, Bringing the Messiah Through the Law, in Human Rights in Political Transitions: GetTrsburg To BosNiA, supra note 4, at 177; Fionnuala Ni Aoláin \& Colm Campbell, The Paradox of Transition in Conflicted Democracies, 27 HuM. RTs. Q. 172 (2005).

70. The ICTY was established during the Balkans conflict but was geographically detached from the site of conflict, while Nuremberg, a post-conflict creation, was established in the state of the site of conflict. Finally, the IST began functioning in a situation of great insecurity, created on site in the midst of continuing insurgency. See David Scheffer, Saddam Trial is a Critical Test for Iraq's Future, Financial Times, Aug. 12, 2005, at 17. 
was created not merely to dispense justice but also to achieve reconciliation in the region, these twin aims have become the measure of the effectiveness of the tribunal. Yet, how is the accomplishment of international criminal justice to advance regional peace? While victor's justice sums up a cognizable relationship of law to power formed over centuries of human experience, the transitional institutions in The Hague and Iraq lack the legitimacy generally associated with a humanitarian intervention.

From its beginning, the ICTY was vulnerable, owing to the many differences between The Hague and Nuremberg. Unlike Nuremberg, The Hague was convened not after but during the conflict, with distinct consequences. Created as a peacekeeping measure by the international community during the conflict, the ICTY lacks the clear authority of victor's justice. As such, the tribunal has lacked full control over the judicial process, whether over the relevant evidence or over the accused, frequently turning to the international community for assistance.

Moreover, since it was established during the conflict, in important ways, the ICTY's aims have been more ambitious than those at Nuremberg. As in the postwar trials, justice was aimed at restoring the rule of law in the region. Yet, having been launched under the Security Council's "Chapter 7" peacemaking powers, however, the international criminal tribunal's purpose was nothing less than to "bring on peace." ${ }^{1}$ If, by this, the aim was deterrence of future violence, the tribunal's success seems tenuous in light of the ongoing massacres. ${ }^{72}$

The Hague tribunal's other purposes transcend the mere cessation of hostilities and involves the aim of societal reconciliation. From its inception, the ICTY pursued an ethno-conscious prosecutorial policy assertedly to foster reconciliation in the region. ${ }^{73}$ It was hoped that condemnation of ethnic persecution, together with individual accountability, would transcend identity politics and advance a shift towards a more liberal order.

Despite this lofty goal, however, the project of reconciliation remains largely aspirational. Given that the ICTY was established by the Security Council as a "peacemaking" measure ${ }^{74}$ the coincidence of the Miloševic indictment with the NATO bombing posed a countervailing symbol of collective attack. When the tribunal declared its intention to indict Bosnian Serb leaders Radovan Karadžić and General Ratko Mladić, these indictments appeared to endanger the delicate balance of peace in the region.

Regrettably, there continues to be massive resistance in the region, even to the mere recognition of past wrongdoings. More than a decade since the 1995 massacre at Srebrenica, the fact of past atrocities has yet to be incorporated in the nation's history. Debate continues to rage over

71. See U.N. Charter ch. VII; S.C. Res. 808, U.N. Doc. S/RES/808 (Feb. 22, 1993).

72. An example is the Srebrenica massacre occurring at this time. For discussion, see Teitel, supra note 69.

73. See Richard Goldstone, Assessing the Work of the United Nations War Crimes Tribunal, 33 STAN. J. INT'L L. 1, 7 (1997) (stressing the importance of prosecuting war criminals).

74. U.N. Charter ch. VII 
responsibility for war crimes, and many cling to their own sense of suffering and historical exceptionalism. Prime Minister Koštunica's ill-fate:' attempt in 2001 to set up a truth commission, doomed from the start by allegations of bias, was disbanded a year later without producing a report. ${ }^{75}$ The ICTY has exacerbated divisions over the region's relationship to the West, the European Union, and the international community.

Lastly, in what this article characterizes as the ICTY's second stage, the challenge is shifting from the international assumption of jurisdiction associated with an apparent nationalist backlash discussed supra to its relegation and to the devolution of power back to national courts. ${ }^{76}$ Moreover, in this latter stage, insofar as there is a perception of either failure or diminished expectations of the ICTY, it has given way to the new international institutions such as the ICC and, thus, a shift to the new generation of tribunals that endeavor to mediate the old national-international dichotomies through the creation of hybrid legal institutions, processes, and jurisdictional principles. ${ }^{77}$

\section{A. Can Justice Buy Peace in Iraq?}

Turning to Iraq, consider the asserted aims of the trials of Hussein and his henchmen. In the midst of extraordinary insecurity associated with the ongoing conflict raging with the insurgency, to what extent can justice buy peace? ${ }^{78}$ Here, some might argue that there is a precedent in the ICTY, convened during the conflict in the Balkans precisely for the purposes of reconciliation and peacemaking. Still, despite the precedent, it remains a tall order for a court to make peace, particularly when, unlike the The Hague, the court is established on the site of ongoing conflict. Indeed, ordinarily the pursuit of justice is thought to be plausibly in tension with peacemaking often understood to involve compromise and closure.

There is a vivid tension in transitional justice's goals in this post-conflict context. For the trial's association with the occupation hints at the goals of not only legitimating the military intervention in Iraq but also supporting the story of regime change. This mix of purposes means considerable tension over transitional justice from the start and, therefore, raises acute dilemmas over the question of the appropriate judiciary and processes. Indeed, the first postponement of the trials arguably reflected a shift in goals and a move away from justification of the intervention toward transitional work, such as the delegitimation of the prior regime and legitimation of the present successor regime. If the goal is to restore legitimacy

75. See Laura Secor, Belgrade Spring, Boston Globe, June 22, 2003, at D1.

76. Regarding the backlash, see Snyder \& Vinjamuri, supra note 47 , at 21 . On the backlash in Croatia, see Victor Peskin \& Mieczylslaw Boduszynski, International Justice and Domestic Politics: Post-Tudjman Croatia and the International Criminal Tribunal for the Former Yugoslavia, 55 Eur.-AsIa Stud. 1117 (2003).

77. See Project on International Courts and Tribunals, Hybrid Courts, http://www. pict-pcti.org/courts/hybrid.html (last visited Oct. 11, 2005).

78. See Robert F. Worth, The Conflict in Iraq: Insurgency, 23 Are Killed in a Series of Attacks Across Iraq, N.Y. Times, Mar. 26, 2005, at A5 (reporting continuing attacks and casualties in Iraq). 
for Iraq, then postponing trials until there is an apt local judiciary in more secure conditions is better than risking a wrong message about the rule of law in this postwar context.

\section{B. Post-Cold War, Post-Conflict Justice}

In its historical postwar context, the main purpose at Nuremberg may well have been the justification of the Allied intervention. ${ }^{79}$ Considering the latest developments, however, the contemporary trials raise the question of to what extent there is an assumed linkage between contemporary transitional justice and the legitimacy of war and its initiation currently characterized as "humanitarian intervention."

Perhaps, not surprisingly, with the lifting of the Cold War political impasse, there has been a conspicuous return to various forms of transitional justice, particularly its international variants. Relatedly, moreover, there is a heightened potential for military intervention. At present, forms of transitional justice are being used as bases for the justifications for humanitarian intervention.

Accordingly, the trials of Milošević and Saddam are not merely aimed at restoring peace in their respective regions. There is a vivid, more complex role to these trials that goes to the broader problem of legitimacy and law's relationship to the use of force. Insofar as the trials characterize the implicated offenses as violations of international humanitarian law, to some degree they will be laying the bases for "humanitarian intervention." While these bases clearly existed in Kosovo and Bosnia, the lack of authority pursuant to convened international proceedings regarding Kosovo nevertheless muddied the waters early on insofar as recognizing bases for international legality. Thus, the ambivalent status of the Hague trials derives from multiple angles: its initial wartime context, its distance from the implicated region, as well as its initiation of the ongoing paradigm shift in international justice. While the shift in the uses of humanitarian law outside of traditional war crimes trials may well aim at advancing political change, so far, there remains an evident lack of political support for the dimension of humanitarian intervention. 81

Yet, what is at stake is also a symbol of another internationalist project, raising squarely the profound question of the legitimacy of the imposition of democracy and the rule of law. Hence, the significance of getting it right in Iraq, while at the same time recognizing that what is going in Iraq, for better and for worse, is sui generis. While analogies are often made to

79. See TAYLOR, supra note 51 , at 575-81 (discussing the primacy of the charge of "aggression" in the Nuremberg Charter).

80. See Robert Meister, Human Rights and the Politics of Victimhood, 16 Ethics \& Int'l Aff. 91 (2002); Simon Chesterman, Just War or Just Peace?: Humanitarian InterVENTION AND INTERNATIONAL LAW 35-44 (2003).

81. However, the process of millennial U.N. reform addresses this proposed change to some extent. See The Secretary General, In Larger Freedom: Towards Development, Security and Human Rights For All, delivered to the General Assembly, U.N. Doc. A/59/ 2005 (Mar. 21, 2005). 
postwar Germany and Japan, these occupations and their trials are distinguishable. Iraq is also distinguishable from the Balkans and Afghanistan because the illegality of the invasion puts additional pressure on post-conflict justice. ${ }^{82}$

The question remains how to achieve some sense of legitimacy in the transition and from where it ought to derive. What is important here, from a genealogical perspective, is that the transition in Iraq ought not be facilely analogized to the post-World War II period nor generalized to elsewhere in the Middle East. Moreover, given what we now know about the timeline of transitions, it is definitely too soon to call the question. ${ }^{83}$

Even in the concededly enhanced climate for international human rights law, its enforcement still remains ad hoc, reflecting the risk of law's politicization. Thus, adjudicating humanitarian law violations constituted a basis to support the intervention in Kosovo. Similarly, the project of prosecution of crimes against humanity will likely be used to lay the basis for justifying the military intervention in Iraq. The contemporary relation international humanitarian law bears to politics and to the legitimation of the use of force highlights the profound tensions and contradictions in the present global paradigm shift.

\section{Conclusion}

This article set out to review contemporary developments in transitional justice from a genealogical perspective. More particularly, it sought to situate the contemporary trials of Miloševic and Hussein within the structure of the arc of transitional justice that began in the mid-twentieth century and culminates in a framing characterized by post-Cold War global politics.

To that end, this article discussed the distinct political circumstances of the present trials of political leaders Slobodan Milošević and Saddam Hussein, addressing these processes' aims and purposes, highlighting areas of commonality and difference. In its remaining parts, this article identified numerous aims of transitional justice and mapped them out onto a genealogy.

In terms of the relevant aims and purposes of transitional justice discussed here, this article compared both processes and discussed the potential for the role of criminal justice in spurring normative regime change. In particular, it analyzed the current emphasis on crimes against humanity as the subject matter that best expresses violations of human rights that go the heart of state repression and abrogation of the rule of law. These developments are seen in tandem with the effects of political and legal globaliza-

82. See Jose Alvarez, Hegemonic International Law Revisited, 97 AM. J. INT'L L. 873 (2003).

83. In my book, I proposed that this was the "paradox of the passage of time" of how our ordinary intuitions are not borne out. TEITEL, supra note 1 , at 62 . My observation has been proven more and more true with the many subsequent trials in Latin America and elsewhere. See Larry Rohter, After Decades, Nations Focus on Rights Abuses, N.Y. Times, Sept. 1, 2005, at A4. 
tion identified in the modern developments in centralization and decentralization of sovereignty and jurisdiction. These ramifications are evident in the current treatment of crimes against humanity and the related efforts towards expansion of the principle of universality.

Lastly, this article discussed the relationship of transitional justice to conflict, suggesting that this relationship has been altered and jeopardized by the complex expanded role of the contemporary international humanitarian law regime. The instant trials reflect the potential for conflicting aims in transitional and post-conflict justice. As the trend towards juridicization continues apace, contemporary adjudications of international humanitarian rights violations serve as both a basis of and a constraint upon humanitarian intervention. From a genealogical perspective, the current trials of Milošević and Hussein appear more and more within a paradigm of post-conflict justice. 